\title{
Prevalence and risk factors of bovine tuberculosis in dairy cattle farms in Egypt
}

\author{
Y.K. Hamed ${ }^{1}$, E.A. Nasr ${ }^{2}$, M.F. Azooz ${ }^{3}$ and H.M. Youssef ${ }^{4}$ \\ ${ }^{1}$ Department of infectious disease, Faculty of Veterinary Medicine, ${ }^{2}$ Department of bacterial diagnostic products, Veterinary \\ Serum and Vaccine Research Institute, Abbasia, ${ }^{3}$ Animal reproduction Research Institute, ${ }^{4}$ Faculty of Veterinary Medicine \\ Cairo University, Cairo, Egypt
}

\begin{tabular}{l} 
Article information \\
\hline Article history: \\
Received March 27, 2020 \\
Accepted April 28, 2020 \\
Available online March 15, 2021 \\
\hline Keywords: \\
Bovine tuberculosis \\
Dairy farms \\
Egypt Risk factors \\
Mycobacterium bovis \\
\hline Correspondence: \\
Y.K. Hamed \\
yassinhamed262@ gmail.com
\end{tabular}

DOI: 10.33899/ijvs.2020.126850.1399, (O2021, College of Veterinary Medicine, University of Mosul.
This is an open access article under the CC BY 4.0 license (http://creativecommons.org/licenses/by/4.0/).

\section{Introduction}

Bovine tuberculosis (BTB) is a chronic granulomatous disease of cattle caused mainly by Mycobacterium bovis ( $M$. bovis). The disease causes significant economic loss in animals, which include reduction in production, restrictions of animal movement, screening costs, culling of diseased animals, and trade restrictions (1). BTB affects cattle around the world, but some countries have been able to reduce the incidence of the disease throughout test and slaughter of the affected cattle herds. Most of Europe and Caribbean countries are free from M. bovis. Bovine TB is endemic in many developing countries mainly in African countries (2). In Egypt the prevalence of BTB in cattle and buffaloes during the 1980 was between $6.9 \%$ and $26.2 \%$ then it reduced to $2.6 \%$ during the 1990 . Then, according to the official report of the General Organization of Veterinary services (GOVs, Egypt), the annual incidence of BTB in 
cattle has been increased, with purchasing of live animals from countries where BTB is prevalent and endemic (3). Epidemiological studies as measurements of disease occurrence and risk factor analysis, transmission in cattle herds are of great importance to be studied (4). Many risk factors were responsible for occurrence of disease in animals include cattle breed, age. also host independent factors are considered more important and include herd size, management practices and cattle purchasing (5-9). Diagnosis of BTB in live animal depends on tuberculin test; the standard method is the comparative intradermal tuberculin (CIDT) test which based on delayed hypersensitivity (10). The CIDT test includes bovine and avian tuberculin used mainly to differentiate between animals infected with $M$. bovis and those sensitized to tuberculin due to exposure to other mycobacterium or related genera (11). ELISA appears to be the most suitable method of the antibody-detection tests and can be a complement, not an alternative, to test based on cellular immunity to detect anergic cows that may be acting as reservoirs of the organism (11-12). So the aim of this study is to estimate the prevalence of BTB disease in some cattle farms in Egypt, identifying the different risk factors play a role in transmission of this organism among cattle on these farms and serodiagnosis of bovine tuberculosis using Indirect ELISA to provide a scientific basis for the development of practical preventive measures.

\section{Materials and Methods}

This study was approved by the Institutional Animal Care and Use Committee (IACUC) in Cairo University. The Reference Number of the approval letter is Vet CU20022020137. The owners of animals known about the purpose of the study before Consent obtained.

\section{Study population and area}

A total number of 5372 dairy cattle in 16 herds from a mid-delta (El-Gharbia), Alexandria Road (Alexandria and El-Beheira) and Upper Egypt (Beni-Suef and El-Fayoum) districts were tested by Comparative Intradermal Tuberculin (CIDT) test. The animals tested were dairy cattle originated from intensive dairy herds ranged from 100-1300 cattle. The majority of dairy cattle were Holstein Friesian, Simmental and Brown. Animals less than 6 months and cows in late gestation period weren't tested. Age of tested cattle was estimated by dentition, information obtained from farm records or animal owners through Questionnaire. The body condition of animals was scored based on Soares et al. (13) and classified as five body condition scores.

\section{Study design}

The study design was cross-sectional and conducted from November, 2015 to April, 2018.

\section{Samples collection}

The sera were collected from 77 positive tuberculin reactor animals. Centrifugation separated the serum at 3000 round per minute for 10 minutes, the serum aspirated carefully by pipette into dry, sterile and labeled test tubes, storage at $-20^{\circ} \mathrm{C}$ until used (14-16) and after slaughtering of 77 animals, postmortem examination was applied and tissue samples (livers, spleens, and lungs lymph nodes) and lymph nodes showing tuberculous-like lesions were collected for bacteriological examination were collected.

\section{Comparative Intradermal Tuberculin Test (CIDT)}

The CIDT test was performed through intradermal injection of bovine purified protein derivative (B-PPD) and avian PPD (A-PPD) according to the method described by Ameni et al. (10).

\section{Indirect Enzyme Linked Immunosorbent Assay (IELISA)}

The indirect enzyme Linked Immunosorbent Assay (IELISA) was applied on sera of 77 tuberculin positive cattle according to the method described by Jarad (17) and Isihak (18) using Bovine Purified Protein Derivatives (B - PPD) as coating antigen from tuberculosis department, Veterinary Serum and Vaccine Research Institute, Abbasia, Cairo. The optical density (OD) was measured at $405 \mathrm{~nm}$ using tecan spectra III ELISA (Mannedorf, Swizerland) reader. Sample was considered positive if it yield a mean OD of each group equal to / or greater than the cut off value \{Cut off value was calculated according to method described by Nassau et al. (19) which equal to the mean OD of negative serum plus 2 standard deviation $\}$.

\section{Post-mortem examination}

After slaughtering of tuberculin positive reactors, postmortem examination was done according to the method described by Corner (20) to detect the presence of suspected tuberculous lesions such as caseation, calcification, or congestion that present in any lymph nodes (head, bronchial, hepatic, mesenteric, prescapular, popliteal and internal iliac lymph nodes). Moreover, specimens were collected from the lung, liver and kidney which showed congestion or suspected tuberculous lesions.

\section{Bacteriological examination}

The organs, lymph nodes and/or tissues showing gross lesions were prepared for bacteriological examination. Samples were cultured on four tubes of Lowenstein-Jensen slants after being decontaminated with $4 \% \mathrm{H}_{2} \mathrm{So}_{4}$ according to the method described by Marks (21). Obtained isolates were identified by conventional methods (rate of growth, colonial morphology, pigmentation, and biochemical properties) in department of bacterial diagnostic products (Tuberculosis department), Veterinary Serum and Vaccine Research Institute, Abbasia, Cairo (21). 


\section{Data statistical and risk factors analysis}

Animal related risk factors (age, breed, body condition score and reproductive status) were recorded when the CIDT test was performed. Dairy farm owners were asked for herd characteristics (herd size, herd management system, presence of neighboring farms, keeping of different animals together, history of disease in the farm and introduction of new cattle in the herd) using questionnaire. All data analysis was carried out using the statistical software program in the statistical researches and studies institute, Cairo University. Association between the occurrence of infection and the risk factors were studied using chi square, odds ratio and confidence interval. The results were expressed as $\mathrm{P}$ value and odds ratio (OR) with $95 \%$ confidence interval (CI 95\%).The result was considered to be significant at $\mathrm{P}<0.05$.

\section{Results}

\section{Results of comparative intradermal tuberculin test in} different districts

The results of tested cattle by using comparative intradermal tuberculin (CIDT) test are shown in (table 1). Out of 5327 dairy cattle, $89(1.67 \%)$ gave positive reaction. The highest result for tuberculin skin test reactors was 22 out of 512 tested cattle $(4.30 \%)$ in mid-delta, while the lowest result was 51out of 4170 tested cattle $(1.22 \%)$ in Alexandria Road district. Out of 16 tested herd $11(68.75 \%)$ were having at least one positive tuberculin reactor. The highest result was 3 out 4 tested herds (75\%) in mid-delta district.

\section{Prevalence of BTB on animal level and associated risk factors}

On the basis of CIDT test the overall individual animal prevalence of BTB at $\geq 4 \mathrm{~mm}$ cut-off points were $1.67 \%$ (95\% CI: 1.3-2.1). The risk factors that were found to be associated with presence of BTB included location mainly in delta region (OR. 3.63, $\mathrm{P}=0.0001$ ), age of animals: mainly 3-6 years (OR. 6.57, $\mathrm{P}=0.0001)$, breed mainly Holstein Friesian (OR. 5.24, $\mathrm{P}=0.0209$ ) and density of cattle in yard (OR. 3.01, $\mathrm{P}=0.000)$ and not associated with body condition scoring (OR. 1.10, $\mathrm{P}=0.8376$ ) and reproductive status of animals (OR. 1.51, $\mathrm{P}=0.9589$ ) as shown in (table 2).

\section{Herd level prevalence and associated risk factors}

Herd prevalence was 68.75 (95\% CI: 34.3 to 123.01) at $\geq 4 \mathrm{~mm}$ cut-off value. The risk factors were found associated with the presence of BTB included history of bovine TB in the farm (OR. 18, $\mathrm{P}=0.036)$, management condition (OR. $18, \mathrm{P}=0.036$ ), Raising different species in the same facility (OR. 41.8, $\mathrm{P}=0.005$ ), purchase of new animals (OR. 40, $\mathrm{P}=0.005)$ and not associated herd size $(\mathrm{OR} .7, \mathrm{P}=0.141)$ and history of BTB in the neighboring farms (OR. 3.33, $\mathrm{P}=0.346$ ) as shown in (table 3 ).

\section{Results of post mortem findings of slaughtered tuberculin reactor cattle}

Out of 77 slaughtered cattle, $66(85.71 \%)$ showed visible and $11(14.29 \%)$ had Non-visible lesions, on the same time the visible lesions showing $8(12.12 \%)$ generalized, 26 (39.40\%) pulmonary, 3 (4.54\%) digestive, 11 (16.67\%) mixed and $18(27.27 \%)$ head as shown in (table 4$)$.

\section{Results of bacteriological examination}

The results showed that, from 77 slaughtered reactor cattle 53 cultures positive were recovered (68.83\%), 50 cultures positive for M. bovis (64.93\%) and $3(3.90 \%)$ for atypical mycobacteria as shown in (table-5). Identification characteristics of 53 mycobacterial isolates revealed that 50 isolates grew at $37^{\circ} \mathrm{C}$, gave smooth colonies without pigmentation in dark or light and 3 grew at $37^{\circ} \mathrm{C}, 42^{\circ} \mathrm{C}$, gave rough colonies without pigmentation in dark or light. The 50 isolates were identified as M. bovis and the 3other isolates as unidentified slow growers.

\section{Results of Indirect Enzyme Linked Immunosorbent Assay (IELISA) \\ IELISA results using bovine PPD as an antigen showed that $31 / 77(40.26 \%)$ were positive (table-6). Out of 66 tuberculin reactor cattle with VL, 29 (43.94\%) were positive and Out of 11 tuberculin reactor cattle with NVL.2 (18.18\%) were positive. The highest result was found in sera of cattle had generalized lesions.}

Table 1: Comparative Intradermal Tuberculin Test in dairy cattle farms in different districts

\begin{tabular}{lccccc}
\hline & \multicolumn{3}{c}{ Tested Herds } & \multicolumn{2}{c}{ Tested animals } \\
\cline { 2 - 6 } & No. & TB positive No. (\%) & No. & CIDT Positive test No. (\%) & CIDT Positive test No. (\%) \\
\hline Alexandria Road & 9 & $6(66.67)$ & 4170 & $51(1.22)$ & $35(0.84)$ \\
Mid-delta & 4 & $3(75)$ & 512 & $22(4.33)$ & $19(3.71)$ \\
Upper Egypt & 3 & $2(66.67)$ & 645 & $16(2.48)$ & $9(1.39)$ \\
\hline Total & 16 & $11(68.75)$ & 5327 & $89(1.67)$ & $63(1.18)$ \\
\hline
\end{tabular}


Table 2: Association of different risk factors to skin test positivity at $\geq 4 \mathrm{~mm}$ cut-off point for bovine tuberculosis

\begin{tabular}{|c|c|c|c|c|c|c|}
\hline Factors & Categories & No of cattle examined & No of positive animals $\%$ & Odds ratio & CI. $95 \%$ & $\mathrm{P}$ value \\
\hline \multicolumn{7}{|l|}{ Location } \\
\hline & Alexandria Road & 4170 & $51(1.22)$ & Ref & & \\
\hline & Mid-delta & 512 & $22(4.30)$ & 3.63 & $2.18-6.03$ & 0.0001 \\
\hline & Upper Egypt & 645 & $16(2.48)$ & 2.05 & $1.16-3.62$ & 0.0130 \\
\hline \multicolumn{7}{|l|}{ Age } \\
\hline & $<3$ years & 2038 & $8(0.39)$ & Ref & & \\
\hline & 3-6years & 2854 & $72(2.52)$ & 6.57 & $3.16-13.66$ & 0.0001 \\
\hline & $>$ byears & 435 & $9(2.07)$ & 5.36 & $2.06-13.97$ & 0.0006 \\
\hline \multicolumn{7}{|l|}{ Breed } \\
\hline & Simmental & 552 & $2(0.36)$ & Ref & & \\
\hline & Holstein Friesian & 4546 & $85(1.87)$ & 5.24 & $1.29-21.35$ & 0.0209 \\
\hline & Brown & 229 & $2(0.87)$ & 2.42 & $0.34-17.31$ & 0.3777 \\
\hline \multicolumn{7}{|l|}{ BCS } \\
\hline & Good & 3088 & 46 (1.49) & Ref & & \\
\hline & Medium & 1934 & 38 (1.96) & 1.33 & $0.86-2.04$ & 0.2027 \\
\hline & Poor & 305 & $5(1.64)$ & 1.10 & $0.43-2.79$ & 0.8376 \\
\hline \multicolumn{7}{|c|}{ Reproductive status } \\
\hline & Pregnant & 3572 & $67(1.88)$ & & & \\
\hline & Non pregnant & 1755 & $22(1.25)$ & & & \\
\hline \multicolumn{7}{|c|}{ The density of cattle in yard } \\
\hline & $<30$ & 2356 & 21(0.89) & Ref & & \\
\hline & $30-50$ & 1190 & $21(1.76)$ & 2.00 & $1.09-3.67$ & 0.020 \\
\hline & $>50$ & 1781 & $47(2.64)$ & 3.01 & $1.79-5.06$ & 0.000 \\
\hline
\end{tabular}

No: Number BCS: Body condition scoring p-values presented at $95 \%$ confidence interval and p 0.05 considered statistically significant.

Table 3: Evaluation of the association of risk factors to herd tuberculin test results

\begin{tabular}{|c|c|c|c|c|c|c|}
\hline \multirow[t]{4}{*}{ Herd factor } & Categories & No of herd examined & No of positive herd\% & Odds ratio & CI. $95 \%$ & p-value \\
\hline & & Herd size & & 7 & $0.73-2.77$ & 0.141 \\
\hline & $<200$ & 8 & $4(50)$ & & & \\
\hline & $>200$ & 8 & $7(87.50)$ & & & \\
\hline \multicolumn{4}{|c|}{ History of BTB in the farm } & 18 & $1.57-3.89$ & 0.036 \\
\hline & Yes & 10 & $9(90)$ & & & \\
\hline & No & 6 & $2(33.33)$ & & & \\
\hline \multicolumn{4}{|c|}{ History of bovine TB in the neighboring farms } & 3.33 & $0.76-2$ & 0.346 \\
\hline & Yes & 6 & $5(83.33)$ & & & \\
\hline & No & 10 & $6(60)$ & & & \\
\hline \multicolumn{4}{|c|}{ Management condition } & 18 & $1.57-3.89$ & 0.036 \\
\hline & Good & 6 & $2(33.33)$ & & & \\
\hline & Poor & 10 & $9(90)$ & & & \\
\hline \multicolumn{4}{|c|}{ Raising different species in the same facility } & 41.82 & $2.29-4.61$ & 0.005 \\
\hline & Yes & 9 & $9(100)$ & & & \\
\hline & No & 7 & $2(28.57)$ & & & \\
\hline \multicolumn{4}{|c|}{ Purchase of new animals } & 40.00 & $2.79-6.31$ & 0.005 \\
\hline & Yes & 11 & 10(90.91) & & & \\
\hline & No & 5 & $1(20)$ & & & \\
\hline
\end{tabular}

No: Number $p$-values presented at $95 \%$ confidence interval and $p \sim 0.05$ considered statistically significant. 
Table 4: Results of postmortem findings of slaughter tuberculin positive cattle

\begin{tabular}{|c|c|c|c|c|c|c|c|c|c|c|c|c|c|c|}
\hline \multirow{2}{*}{$\begin{array}{l}\text { Total No. of } \\
\text { slaughtered } \\
\text { reactor cattle }\end{array}$} & \multicolumn{14}{|c|}{ PM findings } \\
\hline & \multicolumn{12}{|c|}{ VL (66) } & \multirow{2}{*}{\multicolumn{2}{|c|}{ NVL(11) }} \\
\hline \multirow{3}{*}{77} & $\mathrm{Ge}$ & alized & pul & onary & Dig & stive & & xed & & $\mathrm{ead}$ & & $1 \mathrm{VL}$ & & \\
\hline & No & $\%$ & No & $\%$ & No & $\%$ & No & $\%$ & No & $\%$ & No. & $\%$ & No. & $\%$ \\
\hline & 8 & 12,12 & 26 & 39.40 & 3 & 4.54 & 11 & 16.67 & 18 & 27.27 & 66 & 85.71 & 11 & 14.29 \\
\hline
\end{tabular}

No: Number PM: Post Mortem VL: Visible Lesion NVL: Non-visible Lesion \%: Percentage according to the total No. of slaughtered reactors.

Table 5: Bacteriological examination results by using culture method

\begin{tabular}{|c|c|c|c|c|c|c|c|c|c|}
\hline \multirow[t]{3}{*}{ PM finding } & \multirow[t]{2}{*}{ Sites of lesions } & \multicolumn{2}{|c|}{$\begin{array}{l}\text { No. of slaughter } \\
\text { animals }\end{array}$} & \multicolumn{2}{|c|}{ M. bovis } & \multicolumn{2}{|c|}{$\begin{array}{c}\text { Atypical } \\
\text { mycobacteria }\end{array}$} & \multicolumn{2}{|c|}{$\begin{array}{c}\text { Total mycobacteria } \\
\text { isolates }\end{array}$} \\
\hline & & No. & $\%$ & No. & $\%$ & No. & $\%$ & No. & $\%$ \\
\hline & Generalized & 8 & 10.38 & 8 & 100 & 0 & 0 & 8 & 100 \\
\hline \multirow[t]{4}{*}{ I. Visible lesions } & Pulmonary & 26 & 33.76 & 21 & 80.77 & 0 & 0 & 21 & 80.77 \\
\hline & Digestive & 3 & 3.90 & 0 & 0 & 1 & 33.33 & 1 & 33.33 \\
\hline & Mixed & 11 & 14.29 & 6 & 54.54 & 1 & 9.09 & 7 & 63.64 \\
\hline & Head & 18 & 23.38 & 14 & 77.78 & 0 & 0 & 14 & 77.78 \\
\hline Sub total & & 66 & 85.71 & 49 & 74.24 & 2 & 3 & 51 & 77.27 \\
\hline II. Non visible lesions & NVL & 11 & 14.29 & 1 & 9.09 & 1 & 9.09 & 2 & 18.18 \\
\hline Total & Total VL,NVL & 77 & & 50 & 64.93 & 3 & 3.90 & 53 & 68.83 \\
\hline
\end{tabular}

No.: number. VL: Visible Lesion NVL: Non-visible Lesion Total No.: total number in VL\& NVL.

$\%$ of $M$. bovis culture according to total No. of each site which taken.

Table 6: ELISA results (using Bovine PPD) in comparison to PM findings and bacteriological examination

\begin{tabular}{lcccccc}
\hline Site & \multicolumn{2}{c}{ No. of tuberculin positive animals } & \multicolumn{2}{c}{ Bacteriological examination } & \multicolumn{2}{c}{ ELISA } \\
\hline A-visible Lesions & No & $\%$ & No & $\%$ & No & $\%$ \\
1-Generalized & 8 & 10.38 & 8 & 100 & 7 & 87.50 \\
2-Pulmonary & 26 & 33.76 & 21 & 80.77 & 12 & 46.15 \\
3-Digestive & 3 & 3.90 & 1 & 33.33 & 0 & 0 \\
4-Mixed & 11 & 14.29 & 7 & 63.64 & 4 & 36.36 \\
5-Head & 18 & 23.38 & 14 & 77.78 & 6 & 33.33 \\
Total VL & 66 & 85.71 & 51 & 77.27 & 29 & 43.94 \\
B- NVL & 11 & 14.29 & 2 & 18.18 & 2 & 18.18 \\
\hline Total & 77 & 100 & 53 & 68.83 & 31 & 40.26 \\
\hline
\end{tabular}

VL: Visible Lesion NVL: Non Visible Lesion, No: number, B.PPD: Bovine PPD.

\section{Discussion}

Bovine TB caused by Mycobacterium bovis is considered one of the most important diseases facing farming industry, cattle owners, government, abattoir workers and veterinary profession in Egypt. On the basis of the CIDT test the individual animal level prevalence of bovine TB was $1.67 \%$ (95\% CI: 0.7-2.8). These results agreed with that reported by other researchers in Egypt 2.4\%, 1.6\%, and 1.8\% (22-24). In contrast, several authors have reported either low prevalence rates $0.9 \%, 0.13 \%, 0.96 \%$, and $0.30 \%(25-28)$ or high values $11.6 \%, 11.3 \%$, and $4.3 \%(5,7,29)$. The herd-level prevalence of bovine TB was $68.75 \%$; these results agree with $74.1 \%$, $67 \%$, and $65.8 \%(8,30,31)$ and higher than prevalence reported $15 \%, 40.9 \%$, and $40 \%(5,29,32)$. The variation in BTB prevalence may be due to the difference in location, cattle management practices, cattle breeds largely involved in the study, history of BTB in that specific area and purchasing of an infected animal.

The relation between risk factors and BTB in cattle revealed that Age as a risk factor was significantly associated with BTB in cattle dairy farms. There was a significant increase in risk with increasing age up to 6 years then decrease. These results agreed with $(33,34)$. The decrease in 
infection at later stage may be due to development of an anergic state or due to excess mortality of infected animals. Breed as a risk factor was significantly associated with BTB in cattle dairy farms. Holstein cattle showed higher prevalence than Simmental and Brown. These results agreed with some previous studies (35-37). It may be due to most of tested animals in this study from Holstein breed. The prevalence at animal level was significantly associated with different location of farms. It might be due to climatic condition differences in the farms, stress on cattle when kept in poor management and overcrowded environment (38) which may be explain for the high prevalence of BTB in the mid-delta area. An increase in tuberculin positive reactors was observed in cattle kept in high density yards not in large herd size agrees with findings in previous studies $(35,39)$ this may be due to high stocking density and poor ventilation facilitate cattle to cattle transmission.

History of BTB in the farm as a risk factor was significantly associated with BTB in cattle dairy farms. This observation agrees with the results of other studies carried out in many countries which concluded that BTB occur in repeated way in the same areas. These results agreed with that reported elsewhere $(6,40,41)$. It is may be due to the source of infection has not been removed and act as permanent factors for re-emergence of BTB in these areas. Purchasing of new animals has a significant association with BTB. Movements of animals are regarded as one of the most common factors contribute to the spread of BTB and considered as major risk factors in many BTB herd breakdown studies. These results agreed with that reported elsewhere $(7,39,42,43)$. These animals may be infected with BTB due to their contact with many animals during their stay at different dairy farms or at animal markets and may contribute to increasing infection with BTB on the farm.

Management practices and hygiene condition also was significantly associated with BTB in cattle dairy farms and these findings are in agreement with $(38,44)$. Herds kept in farms with poor management have a higher risk of being BTB positive than herds kept in farms with good hygiene as in mid-delta district in Egypt where there are poor hygiene and muddy soil. Poor hygiene condition in a farm may allow M. bovis to remain for a longer period and potentially to proliferate through storage of manure or slurry indoor $(45,46)$. The raising of different species in the same facility as a risk factor was significantly associated with BTB in cattle dairy farms as in previous reports $(8,47)$. In many regions of Egypt, mixed herd with multiple species particularly dairy cattle with goats, sheep and other species managed under intensive management system and act as important factor in recirculation of BTB in cattle dairy farms. On the other hand, the finding that body condition and reproductive status weren't risk factors associated with BTB agrees with previous studies (48). Postmortem findings in (Table-4) were comparable with (49-51) and disagree with $(53,48)$. The number of non -visible lesion (NVL) reactors 11
$(14.29 \%)$, may be attributed to the non-specific reaction to the tuberculin test which may be due to sensitization by other mycobacterium rather than $M$. bovis or closely related microorganisms especially Nocardia or a combination of liver fluke infestation with saprophytic mycobacteria (51). Moreover non-specific reactors may be slaughtered at a stage of invisible lesions of the disease or the lesions may be found in parts of carcass such as bone or skin $(51,52)$.

Bacteriological examination showed that 53 (68.83\%) cultures positive was recovered. The isolation rate of $M$. bovis for visible reactors was $75.75 \%(50 / 66)$. The isolation rate of $M$. bovis for non-visible reactors was 1 (9.09\%). The total recovery rate of $M$. bovis for both visible and nonvisible reactors was $50(64.93 \%)$, these results agreed with $(22,24,53,54)$. and the number of atypical mycobacteria isolates was $3(3.9 \%)$ which agree with $(26,54)$.

The ELISA result showed that $31 / 77$ (40.29\%) were positive, 29 (43.94\%) from serum of animals with visible lesions showed positive results including 7 with generalized lesions 12 with pulmonary lesions, 4 with mixed lesions and 6 of head lymph nodes and out of 11 reactors with NVL 2 $(18.18 \%)$ were ELISA positive .these results were comparable with (51). The result of ELISA test in this study was lower than that of tuberculin test and bacteriological examination which may be due to humeral immune response more dominant in the late stage of infection but cell mediated immune response as in case of tuberculin skin test may appear as early as three weeks post infection (55) So diagnosis of BTB is primarily based on the detection of Cell Mediated Immune responses in live animals (56) and antibody response seen only when animals were in advanced stages of infection or in anergic state (57). So ELISA acts as a complementary to tuberculin test, but it doesn't act alone as diagnostic test for BTB.

\section{Conclusions}

The prevalence of BTB at the individual animal level was associated with age, breed, location and density of cattle in dairy farms. Holstein Friesian breeds, with 3-6 years age, and located at mid-delta district were at higher four-fold risk positivity to comparative intradermal tuberculin compared to $<3$ years old cattle located at Alexandria road being. The herd prevalence of BTB recorded in the present study was higher than other studies. Herds with poor management condition and newly purchased cattle were more likely to be infected with BTB. Purchasing cattle have a significant association with BTB and regarded as one of the most common factors contribute to the spread of BTB and considered as major risk factor. ELISA could be useful as a complementary for tuberculin test in some cases as in the late stages of the disease (anergic cattle). 


\section{Acknowledgements}

The author is grateful to the Faculty of Veterinary Medicine, Cairo University and department of bacterial diagnostic products, Veterinary Serum and Vaccine Research Institute, Abbasia, Cairo, for their support and cooperation.

\section{Conflict of interest}

There is no any conflict of interest regarding the publication of this manuscript.

\section{References}

1. Olea-Popelka F, Muwonge A, Perera A, Dean AS, Mumford E, Erlacher-Vindel E, Forcella S, Silk BJ, Ditiu L, El Idrissi A, Raviglione M. Zoonotic tuberculosis in human beings caused by Mycobacterium bovis-a call for action. The Lancet Infect Dis. 2017;17(1): 21-25. Doi: 10.1016/S1473-3099(16)30139-6.

2. Abubakar UB, Abdulkadir IA, Salisu I, Okaiyeto SO, Kudi AC. Bovine Tuberculosis in Nigeria: A Review. Vet Res. 2011;4(1):3. DOI: 10.3923/vr.2011.24.27

3. Abdellrazeq G, Elnaggar M, Osman HS, Davis WC, Singh M. Prevalence of bovine tuberculosis in egyptian cattle and the standardization of the interferon-gamma assay as an ancillary test. Transbound Emerg Dis. 2016;63(5):497-507. Doi: 10.1111/tbed.12291.

4. Skuce RA, Allen AR and McDowell SW. Herd-level risk factors for bovine tuberculosis: a literature review.Vet Med Inter. 2012;2012(1):10. Doi: 10.1155/2012/621210.

5. Ameni G, Erkihun A. Bovine tuberculosis on small-scale dairy farms in Adama Town, central Ethiopia, farmer awareness of the disease. Rev Sci Tech Inter Epdimol. 2007;26(3):711-720. Doi: 10.20506/RST.26.3.1778.

6. Carrique-Mas J, Medley G, Green L. Risks for bovine tuberculosis in British cattle farms restocked after the foot and mouth disease epidemic of 2001. Prev Vet Med. 2008;84(1-2):85-93. Doi: 10.1016/j.prevetmed.2007.11.001.

7. Habitu T, Demelash A, Adrian M, Girum T, Eystein S, Tadesse G. Prevalence and risk factors analysis of bovine tuberculosis in cattle raised in mixed crop-livestock farming system in Tigray region, Ethiopia. Trans Emerg Dis. 2019;66(1):488-496. DOI: 10.1111/tbed.13050.

8. Tschopp R, Esther S, Jan H, Abraham A, Jakob Z. Risk factors of bovine tuberculosis in cattle in rural livestock production systems of Ethiopia. Prev Vet Med. 2009;89(3-4):205-211. Doi: 10.1016/j.prevetmed.2009.02.006.

9. Aliraqi OM, Al-Jammaly M, AL-Hankawi O, Al-Farwachi MI, Dahl MO. Preliminary Prevalence and Risk Factors of Mycobacterium bovis in Local and Imported Breeds of Cattle and Buffaloes in Mosul city, Iraq. Egyptian J Vet Med. 2020;51(1):83-8. doi: 10.21608/EJVS.2019.17753.1102.

10. Ameni G, Hewinson G, Aseffa A, Young D, Vordermeier M. Appraisal of interpretation criteria for the comparative intradermal tuberculin test for diagnosis of tuberculosis in cattle in central Ethiopia. Clin Vaccine Immunol. 2008;15(8):1272-6. doi: 10.1128/CVI.00114-08.

11. Schiller I, Oesch B, Vordermeier HM, Palmer MV, Harris BN, Orloski KA, Buddle BM, Thacker TC, Lyashchenko KP, Waters WR. Bovine tuberculosis: a review of current and emerging diagnostic techniques in view of their relevance for disease control and eradication. Trans Emerg Dis. 2010;57(4):205-220. Doi: 10.1111/j.1865-1682.2010.01148.

12. Janeiro R. The use of ELISA as a complementary tool for bovine tuberculosis control in Brazil. Braz $\mathrm{J}$ Vet Res Anim Sci.
2006;43(2):256-261.

4456.bjvras.2006.26507.

Doi:

10.111606/issn.1678-

13. Soares FS, Dryden GM. A body condition scoring system for Bali cattle. Asian-Australasian J Anim Sci. 2011;24(11):1587-1594. Doi: 10.5713/ajas.2011.11070.

14. Mohammed AA, Kadir MA. Estimation of some biochemical parameters and trace elements in sheep infested with Taenia hydatigena cysts in Sulaymaniyah province/Iraq. Iraqi J Vet Sci. 2020;34(1):39-44. DOI: 10.33899/ijvs.2019.125543.1065.

15. AlSaad KM, Al-Autaish HN, Ahmed JA. Evaluation of cardiac enzymes and acute phase response as biomarkers for rapid diagnosis of myocarditis in calves with FMD. Iraqi J Vet Sci. 2020;34(1):31-37. DOI: $10.33899 /$ ijvs.2020.163584.

16. Al-Kasar NR, Flayyih MM, Al-Jorany AD. Molecular study of Anaplasma marginale parasite in carrier cattle in Al-Nasiriyah city. Iraqi J Vet Sci. 2019;32(2):299-301. doi: 10.33899/ijvs.2019.153867.

17. Jarad NI, Abbas AK, Aảiz NN. Serodiagnosis of Toxocariasis by ELISA test using anti-T. canis IgG antibodies in stray dogs compared to PCR. Iraqi J Vet Sci. 2019;33(2):367-370. doi: 10.33899/ijvs.2019.163081.

18. Isihak FA, Hassan SM, Shaker BZ, Salih YA. Follow up the antibodies titer against Newcastle disease virus in broiler breeders using ELISA test. Iraqi J Vet Sci. 2020;34(2):295-299. DOI: 10.33899/ijvs.2019.125931.1189.

19. Nassau E, Parsons E, Johnson G. The detection of antibodies to Mycobacterium tuberculosis by microplate enzyme-linked immunosorbent assay (ELISA). Tubercle. 1976;57(1):67-70. Doi: 10.1016/0041-3879(76)90019-2.

20. Corner L. Post mortem diagnosis of Mycobacterium bovis infection in cattle. Vet Microbiol. 1994;40(1-2):53-63. Doi: 10.1016/03781135(94)90046-9.

21. Marks J. Ending the routine guinea-pig test. Tubercle. 1972;53(1):3134. Doi: 10.1016/0041-3879(72)90043-8.

22. Moussa IM, Mohamed KF, Mohamed M, Nasr EA, Shibl AM, SalemBekhit MM, Hatem ME. Comparison between the conventional and modern techniques used for identification of Mycobacterium tuberculosis complex. African J Microbiol Res. 2011;5(25):4338-4343. DOI: $10.5897 /$ AJMR11.425

23. Nasr EA, Marwah M, Abdel Rahman M, Shafeek H. Comparison of modified decontamination methods with culture systems for primary isolation of Mycobacterium bovis from bovine tissues. Benha Vet Med J. 2016;30(1):59-67. DOI: 10.21608/bvmj.2016.31346.

24. Algammal AM, Wahdan A, Elhaig MM. Potential efficiency of conventional and advanced approaches used to detect Mycobacterium bovis in cattle. Microbial Pathogen. 2019;134:103574. Doi: 10.1016/j.micpath.2019.103574

25. Cleaveland S, Darren JS, Sayoki GM, Gabriel S, Rudovick RK, Ernest E, Sharp M. Mycobacterium bovis in rural Tanzania: risk factors for infection in human and cattle populations. Tuberculosis. 2007;87(1):30-43. Doi: 10.1016/j.tube.2006.03.001.

26. Liu YH, Kang Q, Yang B, Li F, Li XQ, Zhang L, Zhao L. Prevalence of bovine tuberculosis in the Aksu Region of Xinjiang, China, between 1985 and 2016. Arquivo Brasileiro de Medicina Veterinária e Zootecnia. 2019;71(2):374-378. DOI: 10.1590/1678-4162-10550.

27. Ramadan HH, El-Gohary HN, Mohamed AA, Nasr EA. Detection of Mycobacterium bovis and Mycobacterium tuberculosis from clinical samples by conventional and molecular techniques in Egypt. Glob Vet. 2012;9(6):648.254. DOI: 10.5829/idosi.gv.2012.9.6.66176.

28. Rocha WV, de Sá Jayme V, de Alencar Mota A LA, de Brito W, de Castro Pires GR, Neto JSF, Ferreira F. Prevalence and herd-level risk factors of bovine tuberculosis in the State of Goiás, Brazil. Semina: Ciências Agrárias. 2016;37(5), 3625-3638. DOI: 10.5433/1679-0359.

29. Ghebremariam MK, Rutten VPM, Vernooij JCM, Uqbazghi K, Tesfaalem T, Butsuamlak T, Idris AM, Nielen M, Michel AL. Prevalence and risk factors of bovine tuberculosis in dairy cattle in Eritrea. BMC Vet Res. 2016;12(1):1-7. DOI: 10.1186/s12917-0160705-9.

30. Bernard F, Vincent C, Matthieu L, David R, James D. Tuberculosis and brucellosis prevalence survey on dairy cattle in Mbarara milk basin 
(Uganda). Prev Vet Med. 2005;67(4): 267-281. Doi: 10.1016/j.prevetmed.2004.11.002.

31. Moiane I, Machado A, Santos N, Nhambir A, Inlamea O, Hattendorf J, Ka“ llenius G, Zinsstag J, Correia-Neves M. Prevalence of Bovine Tuberculosis and Risk Factor Assessment in Cattle in Rural Livestock Areas of Govuro District in the Southeast of Mozambique. PLoS ONE. 2014;9(3):e91527. Doi: 10.1371/journal.pone.0091527.

32. Abdelaal HF, Spalink D, Amer A, Steinberg H, Hashish EA, Nasr EA, Talaat AM. Genomic polymorphism associated with the emergence of virulent isolates of Mycobacterium bovis in the Nile Delta. Scientific reports. 2019;9(1): 1-15. Doi: 10.1038/s41598-019-48106-3.

33. Regassa A, Tassew A, Amenu K, Megersa B, Abunna F, Mekibib B, Ameni G. A cross-sectional study on bovine tuberculosis in Hawassa town and its surroundings, Southern Ethiopia. Trop Anim Hlth Prod. 2010;42(5):915-920. DOI: 10.1007/s11250-009-9507-4

34. Mekonnen GA, Conlan AJ, Berg S, Ayele BT, Alemu A, Guta S, Lakew M, Tadesse B, Gebre S, Wood JL and Ameni G. Prevalence of bovine tuberculosis and its associated risk factors in the emerging dairy belts of regional cities in Ethiopia. Prev Vet Med. 2019;168(1): 81-89. Doi: 10.1016/j.prevetmed.2019.04.010

35. Ameni G, Aseffa A, Engers H,Young DB,Gordon S, Hewinson GR, Vordermeier MH. High prevalence and increased severity of pathology of bovine tuberculosis in Holsteins compared to zebu breeds under field cattle husbandry in central Ethiopia. Clin Vaccine Immunol. 2007;14(10):1356-1361. Doi: 10.1128/CVI.00205-07.

36. Vordermeier M, Ameni G, Berg S, Bishop R, Robertson BD, Aseffa A, Hewinson RG, Young DB. The influence of cattle breed on susceptibility to bovine tuberculosis in Ethiopia. Comp Immunol Microbiol Infect Dis. 2012;35(3):227-232. Doi: 10.1016/j.cimid.2012.01.003

37. Tuncay Ç, Hatipoglu F. The pathology of tuberculosis lesions in allergic skin test (PPD tuberculin) positive cows and detection of tuberculosis agents with PCR in milk samples. Turkish J Vet Anim Sci. 2018;42(3):184-190. Doi: 10.3906/vet-1710-12.

38. 36. Kemal J, Sibhat B, Abraham A, Terefe Y, Tulu KT, Welay K, Getahun N. Bovine tuberculosis in eastern Ethiopia: prevalence, risk factors and its public health importance. BMC Infect Dis. 2019;19(1):19. DOI: $10.1186 / \mathrm{s} 12879-018-3628-1$.

39. Reilly LA, Courtenay O. Husbandry practices, badger sett density and habitat composition as risk factors for transient and persistent bovine tuberculosis on UK cattle farms. Prev Vet Med. 2007;80(2-3):129-142. Doi: 10.1016/j.prevetmed.2007.02.002.

40. White PCL, Benhin JKA. Factors influencing the incidence and scale of bovine tuberculosis in cattle in southwest England. Prev Vet Med. 2004;63(1-2):1-7. Doi: 10.1016/j.prevetmed.2004.02.003.

41. Humblet MF, Gilbert M, Govaerts M, Fauville-Dufaux M, Walravens $\mathrm{K}$, Saegerman C. New assessment of bovine tuberculosis risk factors in Belgium based on nationwide molecular epidemiology. J Clin Microbiol. 2010;48(8):2802-2808. Doi: 10.1128/JCM.00293-10.

42. Johnston WT, Vial F, Gettinby G, Bourne FJ, Clifton-Hadley RS, Cox DR, Crea P, Donnelly CA, McInerney JP, Mitchell AP, Morrison WI, Woodroffe R. Herd-level risk factors of bovine tuberculosis in England and Wales after the 2001 foot-and-mouth disease epidemic. Inter $\mathbf{J}$ Infect Dis. 2011;15(12):e833-e840. Doi: 10.1016/j.ijid.2011.08.004

43. Ullah A, Khattak US, Ayaz S, Qureshi MS, Khan I, Jan IU and Khan MA. Bovine Tuberculosis (bTB): Prevalence and Associated Risk Factors in Large Ruminants in the Central Zone of Khyber Pakhtunkhwa,Pakistan. Pakistan J Zool. 2019;51(1):127-133. DOI: 10.17582/jornal.pjz/2019.51.1.127.133.

44. Romha G, Gebreegziabher G, Ameni G . Assessment of bovine tuberculosis and its risk factors in cattle and humans, at and around Dilla town, southern Ethiopia. Animal Vet Sci. 2014;2(4): 94-100. Doi: 10.11648/j.avs.20140204.12

45. Karolemeas K, McKinley TJ, Clifton-Hadley RS, Goodchild AV, Mitchell A, Johnston WT, Conlan A, Donnelly CA, Wood LN. Recurrence of bovine tuberculosis breakdowns in Great Britain: risk factors and prediction. Prev Vet Med. 2011;102(1):22-29. Doi: 10.1016/j.prevetmed.2011.06.004.
46. Ramírez-Villaescusa AM, Medley GF, Mason S, Green LE. Risk factors for herd breakdown with bovine tuberculosis in 148 cattle herds in the south west of England. Prev Vet Med. 2010;95(3-4):224-230. Doi: 10.1016/j.prevetmed.2010.03.009.

47. Crawshaw T, Daniel R, Clifton-Hadley R, Clark J, Evans H, Rolfe S, De la Rua-Domenech R. TB in goats caused by Mycobacterium bovis. Vet Rec. 2008;163(4):127-129. Doi: 10.1136/vr.163.4.127.

48. Demelash B, Inangolet F, Oloya J, Asseged B, Badaso M. Yilkal A, Skjerve E. Prevalence of bovine tuberculosis in Ethiopian slaughter cattle based on post-mortem examination. Trop Anim Hlth Prod. 2009;41(5):755-765. DOI: 10.1007/s11250-008-9248-9.

49. Shereen AM, Sobhy G, El-Maghraby AS. Assessment of routine and detailed inspection of tuberculous lesions in tuberculin reactor cattle. $\begin{array}{llll}\text { Inter J Microbiol Res. 2015;6(1):155-159. DOI: } & \end{array}$ 10.5829/idosi.ijmr.2015.6.3.964.

50. El-Sify A, Nayel M, Hazem S, Tarabess R, Akram S, Allaam M, El Garhy M. Sero-diagnosis of bovine tuberculosis by ELISA using bovine PPD and ST. CF. J Vet Med Res. 2013;22(1):126-129. DOI: 10.21608/jvmr.2013.77694.

51. Nasr EA, Marwah M, Melika LF, Tammam AA, Gorge SF. Comparison of tuberculin skin test and lateral flow rapid test for detection of bovine tuberculosis in dairy cattle. J Appl Vet Sci. 2016;1(1):21-7. DOI: 10.21608/JAVS.2016.61824.

52. Byrne AW, Graham J, Brown C, Donaghy A, Guelbenzu-Gonzalo M, McNair J, Skuce R, Allen A, McDowell S. Bovine tuberculosis visible lesions in cattle culled during herd breakdowns: The effects of individual characteristics, trade movement and co-infection. BMC Vet Res. 2017;13(1):1-14. doi: 10.1186/s12917-017-1321-z.

53. Sabry M, Elkerdasy A. A polymerase chain reaction and enzyme linked immunosorbent assay based approach for diagnosis and differentiation between vaccinated and infected cattle with Mycobacterium bovis. J Pharm Bioall Sci. 2014;6(2):115-121. doi: 10.4103/0975-7406.126584.

54. Al-Graibawi MA, Mohammad TA, Barak SS. Detection of bovine tuberculosis in three dairy cow stations in Iraq. Iraqi $\mathrm{J}$ Vet Sci. 2014;28(2):69-75. Doi: 10.33899/ijvs.2014.116888.

55. Pollock JM, McNair J, Welsh MD, Girvin RM, Kennedy H E, Mackie DP and Neill SD. Immune responses in bovine tuberculosis. Tuberculosis. 2001;81(1-2):103-107. Doi: 10.1054/tube.2000.0258.

56. De la Rua-Domenech R, Goodchild AT, Vordermeier HM, Hewinson RG, Christiansen KH, Clifton-Hadley RS. Ante mortem diagnosis of tuberculosis in cattle: a review of tuberculin tests g-interferon assay and other ancillary diagnostic techniques. Res Vet Sci. 2006;83(2):190-210. Doi: 10.1016/j.rvsc.2005.11.005.

57. Da Silva EB, De Souza Silva BD, Leon JR, Kipnis A, De Miranda Santos IK, Junqueira-Kipnis A P. Using BCG, MPT-51 and Ag85 as antigens in an indirect ELISA for the diagnosis of bovine tuberculosis. Vet J. 2011;187(2):276-278. Doi: 10.1016/j.tvj1.2009.11.017.

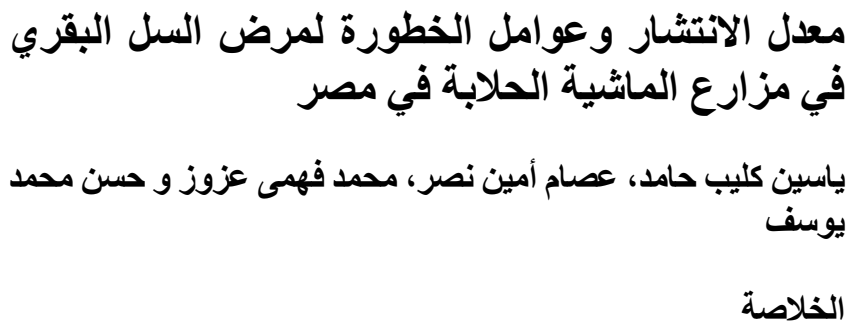

تم إجر اء در اسة مقطعية في الفترة من نوفمبر 10 ـ ب إلى أبريل

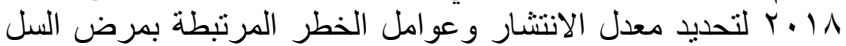

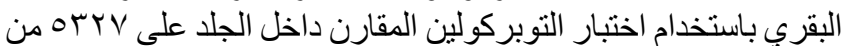

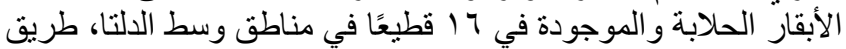

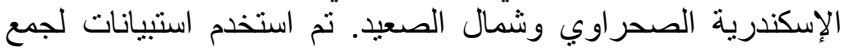

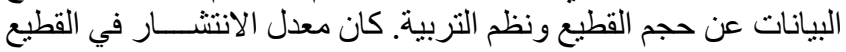




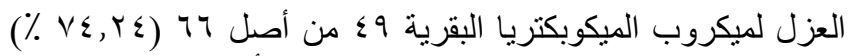

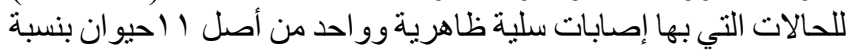

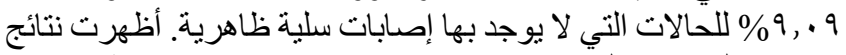

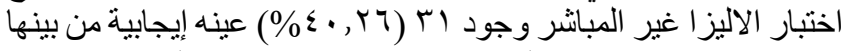

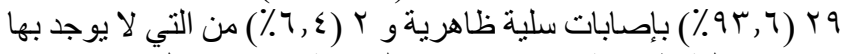

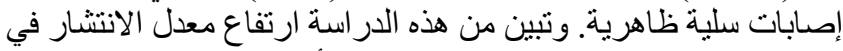

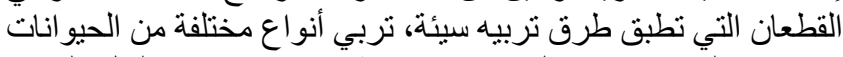

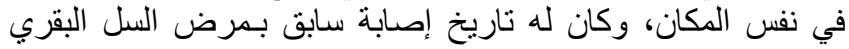

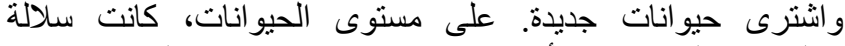

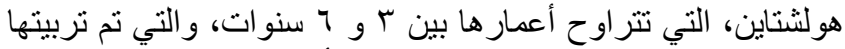

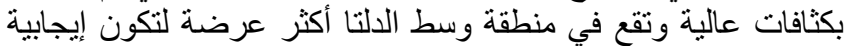
لاختبار التوبركولين الدقارن داخل الجلا.

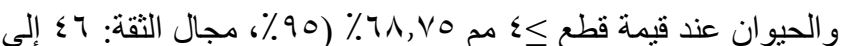

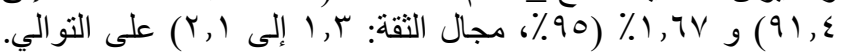

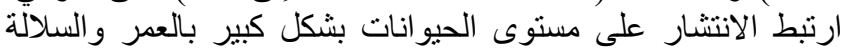

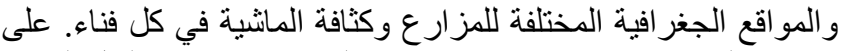

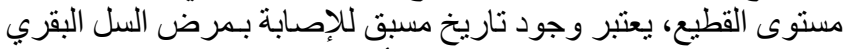

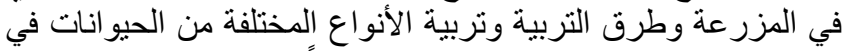

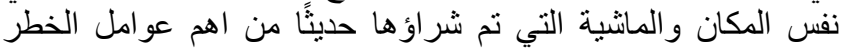

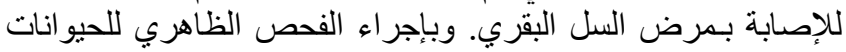

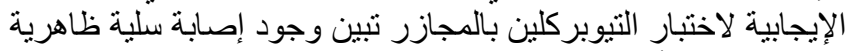

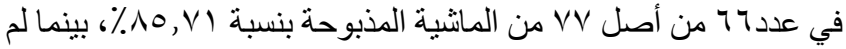

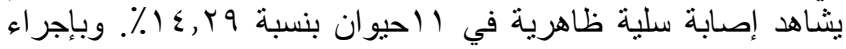
عملية العزل البكتريولوجي للحالات الإيجابية المذبوحة كلها كانت نسبة 